\title{
Gastro-Resistant Tablet plus Rectal Suspension Dosage Form
}

National Cancer Institute

\section{Source}

National Cancer Institute. Gastro-Resistant Tablet plus Rectal Suspension Dosage Form.

NCI Thesaurus. Code C149535.

Combination package consisting of a gastro-resistant tablet and a rectal suspension. 